\title{
Bóg wojny i suplika Sarmaty. Franciszek Ignacy Narocki przed Napoleonem
}

Jacek Wójcicki 


\title{
Jacek Wójcicki
}

\section{Bóg wojny i suplika Sarmaty. Franciszek Ignacy Narocki przed Napoleonem}

\begin{abstract}
Społeczność ówczesna - opisuje Warszawę początku XIX wieku Kazimierz Władysław Wójcicki - miała kilka wydatnych odcieni. Pierwsze miejsce zajmowało owo stare już pokolenie, pamiętające jeszcze czasy Augusta III, króla Leszczyńskiego, a między tymi znajdowałeś i takich, którzy znali Karola XII, bo wiek sędziwy, długoletność nie były taką osobliwością jak teraz. Stuletni starcowie gęsto się przewijali nie tylko po dworach wiejskich, ale i w murach samej Warszawy ${ }^{1}$.
\end{abstract}

Dziejopis stolicy popiera swoje konstatacje fragmentami kroniki rodzinnej („Matka ojca mojego, a babka moja żyła lat 106 i 6 miesięcy") i krążącymi jako wiarygodne opowieściami („Pomiędzy Kurpiami żył bartnik pszczół dzikich, który podług pewnych dat w całej czerstwości ciała i umysłu w sto dwudziestym roku umarł i pochowany został na cmentarzu w Myszeńcu") ${ }^{2}$, a że podważyć ich nie umiemy, wypada zgodzić się na spostrzeżenia autora. Razem z nim jednak dziwilibyśmy się, gdyby jakaś postać powoływała się wówczas na jeszcze wcześniejszych władców. Zdarzyło się tak ponoć w obecności Stanisława Augusta Poniatowskiego, co przypomina następująco Antoni Magier:

W-Wielki Czwartek odbywał się zwyczajnie obchód kwesty na szpitale tutejsze w Zamku, w sali audiencjonalnej (...). Po czym następowało umywanie nóg

\footnotetext{
' K. W. Wójcicki, Spoteczność Warszawy w początkach naszego stulecia 1800-1830, [w:] tenże, Pamiętniki dziecka Warszauvy i inne wspomnienia uarszauskie, wyb. J. W. Gomulicki, opr. Z. Lewinówna, wst. M. Grabowska, t. 2, Warszawa 1974, s. 7.

2 Tamze, przypis autora na s. 8.
} 
starcom w kaplicy, gdzie ciż starcy, siedząc na ławkach i rozzutą każdy mając nogę, tę pobożną od króla odbierali usługę, kiedy jeden z szambelanów, polewając wodą z nalewki srebrnej nogę starca, król podaną sobie serwetą tęż nogę przykrywał. Następnie w pokoju perspektywowym przy nakrytym stole ciż starcy z siwymi brodami w wieku lat najmniej 70, ubrani w żupany karmazynowe, białym pasem przepasani i w białych płaszczach, w liczbie dwunastu w towarzystwie sędziwego kapłana zasiedli. Cześnika koronnego obowiązkiem było podawać królowi talerze, które król nakładając potrawami zaproszonych starców częstował, zapytując się prawie każdego: „Jak się WPan nazywasz? Wiele masz lat?" itp. Jeden z nich nazwiskiem Zakrzewski raz oświadczył, iż podług metryki, którą był opatrzonym, liczył sobie lat 102, iż był przy oblężeniu Wiednia za Jana III i że tam otrzymał rany. Król kazał mu dać czerwonych złotych $10^{3}$.

Najmłodszy giermek, narażony jakkolwiek na niebezpieczeństwa pola bitwy, powinien w roku 1683 mieć przynajmniej piętnaście lat. Wtedy rozmowa z królem mogła odbyć się jeszcze około roku 1770. Ale na początku XIX wieku? Wójcicki ma okazję zadumać się nad takim właśnie problemem, pisze bowiem:

W młodych latach u Orłowskiego, handlującego drzewem a mieszkającego pod Zamkiem warszawskim, widziałem akwarelę arkuszowego formatu, w której był przedstawiony cesarz Napoleon I w orszaku marszałków, jak rozmawia ze starcem po polsku ubranym i podaje mu rękę. Był to Nowakowski, przedstawiony cesarzowi jako towarzysz chorąwi królewicza Jakuba Sobieskiego, która była na wyprawie wiedeńskiej pod buławą króla Jana III. Oswobodzenie Wiednia nastąpiło we wrześniu 1683 r., a przedstawionym został Napoleonowi w końcu 1806. Upłynęło więc 123 lat; gdyby jako towarzysz husarski miał tylko 15 lat, dożyłby przeto $138^{4}$.

Możebne to? A jednak: „Cesarz wyznaczył mu pensją 3000 franków i Nowakowski pobierał ja jeszcze przez lat dwa, bo w początkach 1809 umarł" 5 .

O dziwo, czytelnik tej nieprawdopodobnej opowieści o półtorawiekowym weteranie znajduje potwierdzenie możliwości zjawiska także w słowach medycznego autorytetu z epoki:

Wiele osób wszystkich stanów dosięga najstarszego wieku, a stoletnie osoby u nas nie są rzadkie. W roku 1804 umarł Garnczyński mający lat 117, którego oryginalną metrykę w moich ręku miałem, i który pewnie do starszego wieku jeszcze byłby doszedł, gdyby nie febra katarowa (influenza), która w roku 1800 całą Europę nawiedzała, tak mocno go dotknęła, że sędziwy starzec bez wszel-

${ }^{3}$ A. Magier, Estetyka miasta stolecznego Warszawy, Wrocław 1963, s. 92.

${ }^{4}$ K. W. Wójcicki, op. cit., s. 7-8.

${ }^{5}$ Tamże, s. 8. 
kiej pomocy lekarskiej przezwyciężył wprawdzie chorobę, lecz dawniejszej czerstwości więcej nie odzyskał 6 .

Mało tego. "W podobnym wieku — mówi dalej doktor Wolff — umarł przed lat 15 Narocki, któremu Napoleon pensyją był naznaczył jedynie dla wieku jego"”. Czyżby kolejny obdarowany towarzysz spod Wiednia?

Rozważał tę kwestię Aleksander Kraushar, komentując wzmiankę, zamieszczoną w jednej z francuskich biografii, o petycji, którą Napoleon otrzymał w Warszawie. W tłumaczeniu Kraushara brzmi ona:

\section{Najjaśniejszy Panie!}

Metryka urodzenia mego pochodzi z r. 1690, a zatem mam obecnie wieku lat 117. Pamiętam jeszcze odsiecz wiedeńską i czasy Jana Sobieskiego.

Mniemałem, że się one już nigdy nie powtórzą, a tym mniej mogłem mieć nadzieje ponownego ujrzenia wieku Aleksandra.

Sędziwa starość moja zjednała mi dobrodziejstwa monarchów, którzy tu panowali. O nie też proszę wielkiego Napoleona, w wieku moim zgrzybiałym, przeszło stuletnim, nie będąc już w stanie pracować.

Żyj, Cesarzu, tak długo jak ja. Sława Twoja tego nie potrzebuje, lecz wymaga jej szczęście ludzkości całej.

\section{Narocki ${ }^{8}$.}

Kraushar zauważa, że pamiętniki współczesnych nie wspominają o takim zdarzeniu, „zakrawającym na poetycką legendę” i wytwór entuzjazmu wielbicieli wojennych triumfów cesarza $^{9}$ - dodajmy jeszcze, że podany przez francuskiego biografa tekst dokumentu moglibyśmy uważać wręcz za apokryf wzbogacający pośmiertną napoleońską propagandę (bo samą postać Narockiego i fakt przyznania mu pensji znamy już z rozprawy Wolffa). Historyk polski przypomina jednak inne źródło, pozwalające zweryfikować przytoczony epizod — jest nim prasa, relacjonująca obszernie zarówno manewry wojenne, jak i wszelkie imprezy o charakterze reprezentacyjnym, w których uczestniczył Napoleon podczas pobytu w Warszawie pod koniec 1806 roku (od 19 do 23 grudnia) i na początku 1807 (od 1 do 30 stycznia). Na łamach „Gazety Warszawskiej” („Gazety Korespondenta Warszawskiego i Zagranicznego”) rzeczywiście odnajdujemy następującą notatkę:

Dnia 28 książę Sapieha, czyniący służbę szambelańską przy Najjaśniejszym Cesarzu, przedstawił mu JPana Franciszka Ignacego Narockiego, starca mają-

\footnotetext{
${ }^{6}$ A. Wolff, Rys topografii medycznej miasta Warszawy, „Roczniki Towarzystwa Królewskiego Warszawskiego Przyjaciół Nauk” t. 21, Warszawa 1830, s. 284 (rozdz. 4: Śmiettelnośc między mieszkańcami i choroby pamijace).

7 Tamże.

${ }^{8}$ A. Kraushar, Starzec Narocki wspótczesny Sobieskiemu u cesarza Napoleona w Warszawie 1807 r. (Notatka historyczna), [w:] tenże, Okruchy przeszlości, Warszawa-Kraków 1913, s. 171-172.

${ }_{9}$ Zob. tamże, s. 172.
} 
cego 117 lat, rodem z okolicy Wilna. Temu Monarcha raczył wyznaczyć łaskawie dożywotnią pensyją wynoszącą rocznie 100 napoleondorów, czyli około 3600 złp., i kazał mu zaraz wyliczyć z góry roczną pensyją. Jest on zdrów i czerstwy jeszcze, pamięć ma dotąd wyborną, mówi pięknie i łatwo po łacinie. Prośbę, którą podał Cesarzowi w tymże języku, sam własną ręką napisał, a do tego czysto i bardzo czytelnie. Król pruski wyznaczył był mu także pensyję, lecz tylko 288 złotych na rok $^{10}$.

Kraushar przy tej okazji chwali „sprawność sprawozdawcy”"11, tu jednak przykłada niewłaściwą miarę nowoczesnego reporterstwa prasowego końca XIX wieku do periodyków działających w systemie oficjalnej propagandy. Kontrolowana przez nią prasa zamieszczała wyłącznie nowiny pożądane, a więc nie zawsze prawdziwe, co oczywiście nie wymagało żywej obecności dziennikarzy, a niekiedy wręcz na nią nie pozwalało. Powyższe doniesienie też zapewne powtarza zdania oficjalnego biuletynu. Rzetelności tej informacji możemy jednak domyślać się z detali biograficznych i finansowych, którymi operuje. Z jednej strony dopuszczony przed oblicze cesarza szlachcic legitymował się na pewno oryginalną, sprawdzoną przez urzędników dworu metryką, stąd można ufać podanej tak ściśle dacie urodzin, a nieprawdopodobną na jej tle „odsiecz wiedeńską” uznać za oznaczone wyraziście, acz $z$ dopuszczalną retoryczną przesadą „czasy Sobieskiego” sensu largo ${ }^{12}$. Z drugiej zaś strony należało podać ścisłą sumę, by imponowała na tle dotychczasowej pensji pruskiej. Dopiero tak zestawione szczegóły mają wywrzeć na czytelnikach odpowiednie wrażenie dobroczynności i hojności cesarza, a zarazem świadczyć o prawdomówności gazety, skoro potencjalnie każdy mieszkaniec Warszawy mógł iść do Narockiego z wizytą ${ }^{13}$.

Wieść o szczęśliwym staruszku rozeszła się chyba szybko i szeroko. Wolno domyślać się tego ze wspomnianej przez Wójcickiego „akwareli arkuszowego formatu”. Żeby Narocki przeistoczył się w Nowakowskiego, a ziarno „czasów Sobieskiego”, w których się urodził, urosło za sprawą zwykłej $w$ tak sensacyjnych okolicznościach amplifikacji do konkretu „chorągwi królewicza Jakuba”, musiały towarzyszyć obrazkowi jakieś napisy — prawdopodobnie dlatego nie była to akwarela, lecz kolorowany drzeworyt, niewykluczone, że o charakterze ludowym, jakie rozpowszechniano we Francji napoleońskiej. Za pierwowzór mogła posłużyć rycina Horacego Verneta, zamieszczona w omawianej przez Kraushara publikacji

${ }^{10}$ Dodatek do „Gazety Korespondenta” nr 9 z 30 I 1807 (piątek), cyt. tamże, s.175.

"Tamże, s. 174.

${ }^{12}$ Chronologię uściśla - bez komentowania jej funkcji retorycznej - A. Kraushar, tamże, s. 175; s. 176: „mógł Narocki w dobrej wierze zapewnić Cesarza, iż pamięta czasy Sobieskiego, gdyż dzieciństwo jego wczesne przypadało na epokę, gdy bohater spod Wiednia pielęgnował jeszcze swoje ulubione topole w parku pałacu wilanowskiego".

${ }_{13}$ Tak też — bez podania źródeł - suponuje, cytując fragment wiadomości „Gazety Korespondenta”, Karolina Beylin (Warszawy dni powszednie 1800-1914, wyb. i wst. J. W. Gomulicki, Warszawa 1985, s. 58): „Warszawiacy, przeczytawszy tę wzmiankę w dzienniku, mówili o tym niezwykłym zdarzeniu bardzo wiele, a nawet byli tacy, którzy poszli odwiedzić starca Narockiego (...).

Narocki przyjmował w swoim mieszkaniu licznych gości i opowiadał im o spotkaniu z Napoleonem oraz pokazywał sumę, jaką od niego w darze otrzymał." 
francuskiej ${ }^{14}$ jeśli ona sama $z$ kolei nie stanowiła wariantu lub fragmentu innej kompozycji plastycznej.

Zatem Narocki jest rzekomym Nowakowskim, a należy przypuścić, że i Zakrzewskim $\mathrm{Z}$ wielkanocnej anegdoty Magiera ${ }^{15}$.

"Osnowy supliki Narockiego sprawozdawca nie przytacza” — zauważa Kraushar ${ }^{16}$. Tak jest w istocie, ale tylko w odniesieniu do znanego autorowi numeru „Gazety Warszawskiej”. Idąc wskazanym śladem możemy przekonać się, że czytelnicy otrzymali niebawem znacznie pełniejsze wiadomości o niezwyczajnym petencie:

(...) Franciszek Ignacy Narocki urodzony w Witkach pod Wilnem jest synem Józefa i Anny Narockich, familiji szlacheckiej. W młodości swojej zaciągnął się do wojska; należał później do konfederacyi barskiej, dostał się w niewolą moskiewską i zaprowadzony był do Kazanu; straciwszy szczupły majątek, jaki miał, chwycił się rolnictwa w dobrach jednego plebana. W roku 70 życia swego pojął pierwszą żonę, z którego małżeństwa miał czworo dzieci, w roku 85 zaślubił drugą, ta powiła mu sześcioro dzieci, które wszystkie pomarły, pozostał mu tylko ostatni syn z pierwszej żony. (... $)^{17}$.

Prenumeratorzy „Gazety” poznali również tekst wręczony cesarzowi przez krzepkiego Sarmatę:

Najjaśniejszy Panie! Metryka chrztu mego skazuje rok 1690, a więc mam teraz lat 117. - Przypominam sobie jeszcze czasy Jana Sobieskiego. — Sądziłem, iż się więcej nie wrócą, ale zapewnie mniej jeszcze spodziewałem się ujrzeć wiek Aleksandra. - Starość moja ściągnęła na mnie względy wszystkich monarchów, którzy tu byli, wzywam teraz dobrodziejstwa wielkiego Napoleona, nie mogąc już w wieku moim przeszło stoletnim pracować. - Zyj Najjaśniejszy Panie tak długo, jak ja; chwała Twoja nie potrzebuje tego, ale szczęście rodu ludzkiego tego wymaga ${ }^{18}$.

Monografista Towarzystwa Przyjaciół Nauk, jak widzimy, wykonał pracę zbędną, choć wartościową — jego przekład jest bogatszy leksykalnie i gładszy składniowo. Nic jednak dziwnego, skoro tłumaczył z francuskiego.

Stanisław Szenic wątpi w samodzielność pisarza („Nie wiadomo, kto staruszkowi ułożył suplikę”), niemniej przyznaje, że „była zręcznie napisana i skutek zamierzony osiągnęła, choć

${ }^{14}$ Zob. P.-M. Laurent de l'Ardeche, Histoire de l'empereur Napoléon, illustrée par Horace Vernet, Paris 1839, rozdz. XXV: Campagne de Pologne. Paix de Tilsit, s. 386-387 (wzmianka o Narockim i jego petycja; ilustracja na s. 387).

${ }_{15}$ Tak w komentarzach podaje Juliusz Wiktor Gomulicki, zob. A. Magier, op. cit., przyp. 2 s. 310-311 (tu przypuszczalna data zdarzenia: 1792); K. W. Wójcicki, op. cyt., przyp. 1, s. 517 (tu także przypuszczenie o pierwowzorze „akwareli” bez dyskutowania jej techniki graficznej i funkcji propagandowej).

${ }_{16}$ A. Kraushar, op. cit., s. 175.

17 Dodatek do „Gazety Korespondenta” nr 17 z 28 II 1807 (sobota), s. 267.

18 Tamże, s. 268. 
zaczynała się jawną blagą świadczącą o nieznajomości historii” ${ }^{19}$. Pomijając chwilowo kwestię autorstwa, trudno zgodzić się z taką kwalifikacją początku mowy, na tyle krótkiej, że każdy element ma znacznie większą wagę niż zdarza się to w przeciętnych - czyli o wiele obszerniejszych — popisach oratorskich tamtych lat. Wygłaszał ją wprawdzie ktoś mówiący „pięknie i łatwo po łacinie", lecz wieku nad wyraz podeszłego, co dodatkowo wzmacniało uwage słuchaczy, którzy śledzili nie tylko sens łacińskich zdań, ale wręcz każdy ruch i gest owego — jak nazywa go „Gazeta Korespondenta” - „nadzwyczajnego człowieka”. Czy mówiąc w takich okolicznościach do kogoś obeznanego z historią jak mało kto, będącego jak nikt inny na planecie wcieleniem Historii samej, ktokolwiek porywałby się na „blage”, zaczynając zresztą od dokładnej daty? Powtórzmy więc, że „odsiecz wiedeńska” służy tu za ogólnik i retoryczną przesadę.

Kraushar sądzi, że biograf Napoleona przytoczył mowę Narockiego „według materiału źródłowego, w archiwum francuskim przechowywanego" ${ }^{20}$. Przypuszczenie takie potwierdzałaby inna publikacja napoleońska - monumentalny, komentowany narracją historyczną album sztychów obrazujących dzieje cesarza, gdzie zamieszczone zostało różniące się kilkoma drobiazgami (w tym datą, co jednak można wyjaśnić prostą omyłką zecerską, wynikającą z podobieństwa pisanych cyfr „8” i „5”) tłumaczenie petycji Narockiego (występującego tu — to te ż w sumie nieistotne - jako „Naroki”) oraz jego krótki życiorys ${ }^{21}$. Ponieważ trudno przypuszczać, by komponując we Francji historię panowania Napoleona sięgano często do prowincjonalnych (wobec Paryża) pism krajów satelickich, można rzeczywiście przyjąć, że

19 S. Szenic, Larum na traktach Warszauy, Warszawa 1960, s. 177 (rozdz. Napoleon i stuletni starzec).

${ }^{20}$ A. Kraushar, tamże.

${ }^{21}$ Zob. A. V. Arnault, Vie politique et militaire de Napoléon... Ouvrage orné de planches litographiéex... t. 1-2, Paris 1822-1826; t. 2 s. 70: „Le 25 janivier, un viellard lui présenta cette pétition:

"Sire,

Mon extrait de baptême [Laurent de l'Ardeche, op. cit., s. 386: Mon extrait baptistaire] date de 1690, donc j'ai à présent 117 ans.

Je me rappelle encore la bataille de Vienne et les temps de Jean Sobieski.

Je croyais qu'ils ne se reproduiraient plus, mais assurément je m'attendais encore moins à revoir le siècle d'Alexandre.

Ma vieillesse m'a attiré les bienfaits de tous les souverains qui ont été ici, et je réclame ceux du grand Napoléon, étant, à mon âge plus que séculaire, hors d'état de travailler.

Vivez, sire, aussi long-temps que moi; votre gloire n'en a pas besoin, mais le bonheur du genre humain le demande.

Naroki».

Cette pièce, écrite tut entière de la main du signataire, n'énonşait rien qui ne fût vrai. Né aux environs de Wilna, d'une famille noble, Naroki avait suivi d'abord la carrière des armes; en 1769, entré dans la confédération de Bar, et combattant pour l'indépendance de son pays contre les Russes, il avait été pris par eux et envoyé en Sibérie. Sa fortune ayant été détruite par sa déportation, à son retour il s'était fait fermier. Quand il songea, à se marier, il était déjà septuagénaire; devenu veuf, il s'était remarié à quatre-vingt-six ans; il avait eu de ces deux mariages dix enfans, auxquels il survivait.

Le roi de Prusse, par égard pour le grand âge de Naroki, lui faisait une pension mensuelle de vingt-quatre florins de Pologne, équivalent à quatorze livres huit sous de France. L'empereur accorda à ce doyen des soldats alors vivans une pension de cent napoléons, dont une année fut payée d'avance".

Egzemplarz Biblioteki Narodowej w Warszawie sygn. A. 3983 / G. XIX / V-157 (ze zbiorów dawnej Biblioteki Krasińskich) zawiera odręczną notatkę: Achete à Petersbourg ce 30 mars 1840 chez la libraire Brieff par le comte Vincent Krasiński. Streszcza się w niej szmat zawikłanych dziejów Europy: generał szwoleżerów przypominający sobie wspólne zmagania i nadzieje, pochylony nad bibliofilskim foliantem, za niemałą sumę nabytym w stolicy carów... 
ogłoszone w warszawskiej gazecie dossier opracowano na podstawie materiałów zatwierdzonych centralnie.

„Zręczna propaganda francuska umiała rozgłosić i ten drobny gest Napoleona” — komentuje pensję dla Narockiego Szenic ${ }^{22}$, mając na myśli artykuł "Gazety Warszawskiej” i sztych Verneta. Zanim sprawdzimy, czy rzeczywiście da się na tym niewielkim przykładzie uchwycić jakieś mechanizmy propagandowej maszynerii, sięgnijmy — o ile to możliwe w głąb archiwów Cesarstwa.

Uczynił to Adam Skałkowski, a jego poszukiwania przyniosły efekt potwierdzający prasowe doniesienia ${ }^{23}$. Przetrwał do dziś dekret Napoleona przyznający dożywotnią pensję Narockiemu - chociaż z datą 27 stycznia, co każe stanowczo sprostować datę „Gazety Korespondenta” i uwierzyć pracy Arnaulta, pomyłkę cyfrową przysądzając raczej zecerowi polskiemu niż cesarskiej kancelarii (bo nie wydaje się możliwe, by cesarz raczył przygotować awansem decyzję dla mającego się nazajutrz stawić petenta) ${ }^{24}$. Audiencja miała zatem miejsce 25 stycznia. W dokumentach zachowało się również lacińskie podanie:

\begin{abstract}
Augustissimo Gallorum Imperatori, Italiae Regi serenissimo, fortunato et invicto bellatori salutem infra scriptus orator.

Gentis meae Polonae forsitan decanus, natus scilicet saeculo bellatoris nostri Sobiescii annum agens vitae centesimum decimum septimum cum coninge mea secundi voti annorum septuaginta quattwor, viso magnae gentis Gallicae magno exercitu, sub auspiciis Augustissimae et serenissimae Caesareae Regiae Maiestatis vestrae liberantis nos plus quam ab Aegyptica Russorum ac Germanorum servitute, exclamare possumus ad Deum cum evangelico Simeone: "Nunc dimittis servum tuum Domine secundum verbum tuum in pace, quia viserunt oculi mei salutare tuum, quod parasti ante faciem omnium populorum". Sed cum ad leges militares de statione non liceat decedere, donec Supremus terrae caelique Imperator mandet, et stationario cum vetula consorte virium deficiente subsidio ipsa etiam desint alimenta, a restauratore et patre patriae peto panem. Augustissimae et serenissimae Caesareae Regiae Maiestatis vestrae pauper sed fidelis subditus Franciscus Narocki. Datum Varsaviae in suburbio Nowy Świat dicto in aede Olszewski $N^{\circ} 158^{25}$.
\end{abstract}

22 S. Szenic, op. cit., s. 179.

${ }^{23}$ Zob. En marge de la correspondance de Napoléon I. Pièces inédites concernant la Pologne 1801-1815, opr. A. Skałkowski, Warszawa 1911 (odb. z „Kwartalnika Historycznego” R. XXIV: 1910, s. 537-618: Miscellanea V; Z nieogtoszonych listów, not $i$ dekretów Napoleona).

${ }_{24}$ Archives Nationales à Paris, sygn. A. F. IV 239 pl. 1602 (tamże, s. 11-12; Z nieogloszonych listów ... s. 546-547): Décret. Varsovie, 27. janivier 1807

Art. 1. Il est accordé une pension viagère de deux mille francs au sieur François Ignace Narocki, né à Witki près Wilna le 28. novembre 1690 et demeurant à Varsovie.

Art. 2. Cette pension sera payée par sémestre à commencer du $1^{\text {er }}$ du présent mois.

Art. 3. Notre intendant général et notre trésorier général sont chargés de l'exécution du présent decret.

${ }_{25}$ Tamże, przyp. 2. 
Jak widać, to wcale nie podstawa tekstu petycji zamieszczonego w „Gazecie Korespondenta" i przytaczanego przez francuskich historyków. Skałkowski nie cytuje też innego tekstu łacińskiego ani francuskiego. Trzeba więc przyjąć, że to jest właśnie jedyny prawdziwy oryginał przygotowanego przez starca podania.

Aby jednak stało się zadość dokumentalnej rzetelności, należy porównać publikację zasłużonego historyka doby napoleońskiej ze źródłem.

Okazuje się, że w obrębie archiwalnej plaquette nr 1602 zachowało się pod datą 27 stycznia 1807 kilka dokumentów dotyczących naszego bohatera, które nie tylko dowodzą skrupulatności cesarskiej kancelarii, lecz także pozwalają uściślić niektóre informacje podane przez Skałkowskiego.

Badacz cytuje dekret bez zwyczajowej inicjalnej formulki Napoléon, l'empereur des Français et roi d'Italie. Nous avons décrété et décrétons ce qui suit..., i to można zrozumieć, nie dowiadujemy się jednak - a szkoda - iż w całości jest on zanotowany ręką Bonapartego (z wyjątkowo bogatym jak na niego podpisem „Nap.”!), co świadczyć może o większym niż zdawkowe zainteresowaniu władcy sprawą starca ${ }^{26}$.

Następny dokument (zaopatrzony w archiwum francuską notką na osobnej karteczce) nie pozostawia wątpliwości, że Narocki „sam własną ręką napisał, a do tego czysto i bardzo czytelnie" łacińską prośbę. Nagłówek zajmuje, jak należy, całą szerokość arkusza, zasadniczy tekst, pisany pagina fracta, dzieli się na dwa wyraźne akapity (niestety nie zaznaczone graficznie w znanym nam druku), a podpis „ubogiego, acz wiernego sługi”, zgodnie z konwencja, drobnymi krokami drepcze w dolnym rożku podania, gdzie wygasa skrótem „mpp” — „manu propria". Pewność ręki i zamaszystość pisma imponują tak samo, jak wzruszają drobne błędy i potknięcia w tekście: „saecundivoti”, "quatuor", „exertu”, „a Deum” czy poprawiane starannie "decedere".

Jest w piśmie Narockiego wigor, którego brakuje ładnej i poprawnej, lecz sztywnej kaligrafii kopisty — okazuje się bowiem, że petycja zachowała się nie w jednym, lecz w dwóch egzemplarzach. Jej kopia dotarła na warszawski Zamek zapewne już tydzień przed audiencją, ponieważ na marginesie czytamy uwagę adiutanta:

Nommé François Narocki âgé de 117 ans avec une femme de 74 se trouvant dans la misère demande une pension. Varsovie, le 20 janivier 1807. Falkowski capt ${ }^{27}$.

\footnotetext{
${ }^{26} \mathrm{Z}$ opisu Skałkowskiego można wnosić, że dekret jest kopią ręki sekretarza stanu Hugues Mareta, tymczasem chodzi wylącznie o dopiski kancelaryjne; zbędna kropka („Dela main de Maret. En marge:” itd.) wystarczyla, by utrwalić fałsz.

${ }^{27}$ Autorem notki jest Hipolit Falkowski (1779-1821); niedługo przedtem to on uczył cesarza po bitwie pod Pułtuskiem rozmowy z żołnierzami piątego korpusu: „Nie rozumiał Napoleon, co to jest «chleba», dopiero przywołali kapitana Falkowskiego, aby go po polsku nauczył, jak odpowiedzieć: «nie masz chleba»”... (J. Kierzkowski, Pamiętniki, Warszawa 1903, s. 126 - cyt. za: Dat nam przyktad Bonaparte. Wspomnienia i relacje żotnierzy polskich 1796-1815, wyb. i opr. R. Bielecki, A. Tyszka, t. 1, Kraków 1984, s. 153).
} 
W obu egzemplarzach widnieje taki sam, bardzo wyraźny adres petenta, który Skałkowski zacytował błędnie - ówczesny „dom Olszewskiego” nosił numer hipoteczny $1308^{28}$.

Pomiędzy oryginałem i kopia podania znajdujemy wreszcie jeszcze jeden dokument, wnoszący do raczej bezdusznych archiwów oddech życia, zarówno przez to, co głosi, jak i przez sam wygląd. Oto przed nami wielokrotnie składana i poprzecierana na zgięciach metryka, pisana w odstępie długiego czasu dwoma charakterami pisma:

\section{Laudetur Iesus Christus!}

Infra scriptus requisitus super extradendo testimonio legitimi ortus et baptismi exprimendae personae, illud ex libro metrices baptisatorum ad ecclesiam parochialem Ucianensem extraxi, prout sequitur:

Witki villa: die $28^{v o}$ Novembris 1690 anno. Ego Adalbertus Strutynski praepositus Ucianensis baptisavi filium duorum nominum Franciscum et Ignatium generosorum Iosephi et Annae Narocki coniugum legitimorum. Patrini fuere generosi Michael et Catharina Pruszakiewicz coniuges.

Quod ita reperitur testor, meque in meliorem fidem subscribo, ac sigillum ecclesiae sub titulo S. Stanislai episcopi et martyris appono. Datum in residentia praepositurali die $26^{\text {to }}$ Octobris 1769 anno in Uciana.

$$
\text { (L. S.) }
$$

Casimirus Sawiński vice-praepositus et mansionarius ecclesiae eiusdem mpp.

Poniżej tego ekstraktu, sporządzonego w najburzliwszym czasie konfederacji barskiej, dopisano później:

\footnotetext{
${ }^{28}$ Musiała to być świeża transakcja, ponieważ jeszcze Taryfa czyli opis wszystkich pałaców, domów, kościołów, szpitalów i ich posesorów miasta Warszawy dla wygody publicznej urydana w roku 1807, [Warszawa,] Nakł. J. L. Kocha [1807], jako właściciela kamienicy podaje obywatela Mścichowskiego (s. 46). Dopiero Taryfa domów miasta Warszawy dla wygody publicznej wydana naktadem S. Z[adory] $w$ roku 1807 w miesiącu wrześniu, a poprawiona stosownie do nowego podzialu na cyrkutów osiem w miesiq̨u lipcu 1808 roku, [Warszawa,] w druk. Ragoczy, [1808], zamieszcza nazwisko Olszewskiego (s. 43). Dom był jego własnością jeszcze w roku Bitwy Narodów (zob. Taryfa domów miasta Warszawy... uydana nakladem S. Z. w roku 1813, [Warszawa,] druk. sukcesorów Ragoczych, [1813], s. 43).

Nazwisko późniejszego nabywcy - „Kielc” - wymienia Taryfa domów miasta Warszau'y... nowo ưdana, $z$ dotąceniem przedmieścia Pragi i domów za rogatkami będących w miesiq̨cu styczniu 1817 roku, [Warszawa,] dr. sukcesorów Wiktora Dąbrowskiego [1817], s. 41. W roku 1819: „1308. Franciszek Koeltz. Kamienica murowana $\mathrm{z}$ piętrem od frontu, od tyłu po lewej stronie oficyna murowana $\mathrm{z}$ piętrem, wystawa drewniana, po prawej komórki na drzewo, w ogrodzie altanka i kręgielnia" - Źródla do dziejów Warszawy, t. 2: Wykaz nieruchomości miasta Warszauy z 1819 roku, wyd. J. Kazimierski, Warszawa 1966 (Materiały do Dziejów Miast Polskich 2), s. 111 (Cyrkut 6 - Ulica Nowy Świat). Ciekawe, czy Narocki grał jeszcze w kręgle?... Obecnie jest to nr 52 zob. J. Zieliński, Ulica Nowy Świat, Warszawa 1998 (Ulice Mojego Miasta), s. 124.

Zapewne to poprzedni właściciel był wówczas posiadaczem posesji na południowym odcinku ulicy, o numerze hipotecznym 1267, późniejszym policyjnym 15: „Tomasz Olszewski. Dom drewniany od frontu, w podwórzu po prawej ręce oficyna drewniana, za którą komórki drewniane, po tejże stronie dom drewniany z piętrem, w tyle stajnia i wozownia" (Źródla do dziejów Warszawy, op. cit., s. 108); por. J. Zieliński, op. cit., s. 122. W tym miejscu (róg Nowego Światu i Alej Jerozolimskich) stał m.in. budynek hitlerowskiego Café Clubu.
} 
Quorum interest aut quomodolibet interesse poterit notum testatumque facio hancce copiam metrices baptismi generosi Franciscis Ignatii Narocki ad praesens in parochia Varsaviae S. Crucis manentis in platea dicta Alexandria sub numero 2782 quoad omnia verba et puncta concordare cum primitivo extractu de libris metrices ecclesiae Ucianensis sub data 26 Octobris anni 1769. In quorum fidem has litteras sigillo ecclesiae munitas manu propria subscribo. Datum Varsaviae ad Sanctam Crucem anno 1802 die 22 Martii.

\section{Iosephus Różycki praefectus ecclesiae Varsaviae Sanctae Crucis ${ }^{29}$}

Wyciąg został zaopatrzony w owalną pieczęć opłatkową parafii Św. Krzyża, odciśniętą na ozdobnej papierowej wycinance.

Pora zastanowić się nad charakterem działań propagandowych związanych z petycją.

Narocki przedstawia się jako „niżej podpisany mówca”, co potwierdzałoby przekonanie, że petycja została nie tylko wręczona, ale również wygłoszona (zgodnie z regułami sztuki) lub przeczytana (zważywszy wiek osoby przemawiającej). Jak przypuszczaliśmy, „wiek Sobieskiego" to określenie czasu i nie ma w ogóle wzmianki o odsieczy wiedeńskiej ani tym bardziej o udziale w niej mówiącego. Atmosfera militarna panuje jednak od samego początku już w tytulaturze Napoleona, skróconej w wersji polskiej i francuskiej do prostego wezwania „Sire” „Najjaśniejszy Panie”. Władca został po lacinie nazwany nie tylko cesarzem Francuzów i królem Włoch, ale prócz tytułów oficjalnych obdarzony także mianem „najjaśniejszego, szczęsnego i niezwyciężonego wojownika”, co powtórzyło się echem w epitecie „,bellator” Jana Sobieskiego z zasadniczej części petycji, tworzącej dwuzdaniowy, przeciwstawny okres retoryczny.

Na wstępie rzymska stylizacja tytułu ustępuje odwołaniom biblijnym. Cesarz ze swym wojskiem występuje jako wybawiciel Polaków „z gorszej niż egipska niewoli rosyjskiej i niemieckiej”. Pod koniec pierwszego, długiego zdania mówca ucieka się tym razem do Nowego Testamentu — do obrazu łączącego starość, nadzieję i religijne uniesienie: błogosławieństwa Symeona z Ewangelii według świętego Łukasza (Ek 2,29-31). Druga część okresu powtarza zaś motyw wojskowy: nowy Symeon nie może odejść z postoju, dopóki Najwyższy Władca nieba i ziemi nie rozkaże, bo to wbrew żołnierskiej dyscyplinic.

Przed cesarzem nie stoi więc bezradny i niedołężny starzec, lecz najbardziej poważany w obozowym kole rycerz — „decanus”, 'dziekan', 'senior', co zresztą spodobało się autorom francuskim („,e doyen des soldats alors vivans” u Arnaulta) - domagający się tymczasem od „odnowiciela i ojca ojczyzny” opatrzenia w wojennej potrzebie.

\footnotetext{
${ }^{29}$ Adres Narockiego z czasów pruskich (ul. Aleksandria nr 2782) to teren - zrujnowanego wówczas po pożarze z ok. 1785 roku — pałacu słynnego podróżnika i wodza, księcia Karola Henryka Mikołaja Ottona de Nassau-Siegen (1745-1808), którego pamięć przetrwała w popularnej nazwie tego fragmentu miasta „Dynasowskie" i późniejszej ulicy Dynasy. Por. Opis wszystkich pałaców, domów, kościołów, szpitalów i ich posesorów miasta Warszawy dla wygody publicznej wydany w roku 1797 - Verzeichnis sämtlicher in der Stadt Warschau befindlichen Häuser..., [b. m. dr., 1797], s. 91; A. Magier, op. cit., s. 445, 451. W roku pobytu Napoleona w Warszawie posesja była juz rozparcelowana - Taryfa z 1807 roku wymienia pod tym samym numerem trzy pałace: de Nassau, Bauera i Le Fevre (op. cit., s. 97); od następnego roku dłuższy czas w spisach figurują już: pałac de Nassau (nr 2782 a) i drewniany dom Bauera (nr 2782 b). Dziś w tym miejscu stoi gmach Teatru Polskiego; dawna ul. Aleksandria to obecnie ul. Karasia i część ul. Kopernika (na przedłużeniu ul. Karasia do Ordynackiej).
} 
Petycja Narockiego pozostawia bez wątpliwości dwie sprawy. Pierwszą jest kunszt retoryczny (złączony z rzadką cnotą zwięzłości, zapewne warunkowanej realiami cesarskiej audiencji) i umiejętność połączenia najbliższego sercu Sarmaty motywu ewangelicznego ze stylizacją wojskową. Druga — nadzieje wobec Napoleona jako zbawcy Polski.

Obie zostały przez oficjalną propagandę przekształcone i stonowane. Czasy Sobieskiego jako określenie partykularne dookreślono, najprawdopodobniej w pośpiechu, nonsensownym chronologicznie przywołaniem odsieczy Wiednia, co — jak widzieliśmy - miało dalsze konsekwencje dla legendy Narockiego. Wyeliminowano również motywy biblijne, zastępując je przypomnieniem Aleksandra Macedońskiego. Postać ta, aczkolwiek Polakom znana, nie wzbudzała tych samych refleksji co figury historii republikańskiego Rzymu, bliższe nawet w tragicznych konotacjach wojen domowych czasów Cezara czy Oktawiana. Aleksander Wielki to jednostka, zdobywca, jedynowładca — skojarzenia polskiemu myśleniu szlacheckiemu obce i wrogie zbiorowości, stabilności pokoju i wspólnej mądrości Rzeczy Pospolitej. Cóż, kiedy z dostępnych paraleli antycznych ta najściślej pasowała do Bonapartego idącego przez świat, by czynić go sobie poddanym.

Wzmianki o dobrodziejstwach poprzednich władców u Narockiego w ogóle nie ma w wersji oficjalnej urosła ona jeszcze do postaci komentarza wymieniającego kwotę przyznaną przez skąpego króla Prus. To tylko tło, na którym nie ma być widoczna zdjęta z karabeli, złożona do prośby garść obdarowanego, lecz hojna dłoń sypiącego złotem suwerena.

Końcowe zdanie jest kunsztownym — zbyt francuskim — komplementem pod adresem Napoleona, przenoszącym znowu akcent logiczny na jego osobę. Zauważmy, że w tej wersji korona cesarskiej chwały nie zawiera żadnego szczegółu, który by był ważny dla polskiego mówcy - głucho o wskrzeszeniu Polski i nadziejach Polaków.

W słowach Narockiego był więc Napoleon wskrzesicielem Polski godnym mesjańskich aluzji - w oficjalnej, podanej do wierzenia wersji cesarz to nie zbawca, lecz przede wszystkim zdobywca. Dla prezentacji takiego obrazu na francuską modłę nie wahano się skłamać; podkreślając przesadnie akcent odsieczy Wiednia zagubiono jednocześnie jego sakralne znaczenie, oczywiste i pierwszorzędne dla każdego Polaka.

„Dalsze losy Narockiego nie są znane, nie wiadomo, ile lat pobierał ze skarbu francuskiego wspaniałą rentę starczą. Upadku Napoleona pewnie już nie dożył” — przypuszcza dalcj Szenic $^{30}$. Źródła potwierdzają udział Narockiego w konfederacji barskiej od 14 II 1769 i jego pobyt w Tobolsku na Syberii w latach $1772-1774^{31}$. Ostatni rok życia biogram określa na 1809, zapewne za wzmianką Wójcickiego o Nowakowskim z akwareli. Tymczasem artykuł Wolffa o długowiecznych mieszkańcach stolicy wymieniał liczbę piętnastu lat wstecz, co

\footnotetext{
${ }^{30}$ S. Szenic, tamże.

${ }^{31}$ Zob. biogram pióra Wacława Szczygielskiego, Polski Stownik Biograficzny, t. 22, Wrocław 1977, s. 545 (daty: 1690-1809; badacz nie powołuje się na przytoczony powyżej wyciąg metrykalny, sporządzony 26 X 1769 w Ucianie, gdzie Narocki dotarł niewątpliwie wraz z oddziałem Jana Bachowskiego); F.-A. Thesby de Belcour, Konfederaci barscy na Syberii (1774), wyd. A. [Kraushar,] Kraków 1895 (odb. z dwutyg. „Świat”) rejestr nazwisk konfederatów s. 15-160; s. 47: Narocki Franciszek z konfederacji warszawskiej.
} 
czyniłoby rok 1814 lub 1815. Osiemdziesięcioletni pułkownik barski, sto siedemnastoletni oddawca petycji, dokonałby zatem żywota w sto dwudziestej piątej wiośnie?

I tu możemy posłużyć się źródłami współczesnymi o różnym stopniu wiarygodności jak dostrzegamy na przykładzie działań propagandowych wobec petycji Narockiego - ale w niektórych szczegółach niezastąpionymi i nie mającymi powodu kłamać, zwłaszcza w nekrologii. W „Gazecie Warszawskiej” z 13 stycznia 1816 istotnie jest wiadomość o zgonie „W tych dniach" Narockiego ${ }^{32}$. Potwierdzałoby to słowa Wolffa i daje asumpt do ujęcia tak aktywnego życia jednego z sarmackich rycerzy datami 1690-1816.

To jednak nie koniec archiwalnych odkryć. W warszawskiej Bibliotece Narodowej, gromadzącej zbiory dawnej Biblioteki Krasińskich, zachował się pod sygnaturą 2.019.802 (dawniej Kras. 56393) dwukartkowy druczek ulotny bez daty: Wiersz na pochwatę Wielkiego Napoleona Cesarza Francuzów, Króla Wtoskiego, przez Franciszka Ignacego Narockiego, niegdyś wojsk polskich porucznika, a teraz $w$ wieku sto dziewiętnastym będącego, po odebraniu od N[ajjaśniejszego] Cesarza wyznaczonego do życia funduszu $w$ dowód $w$ dzį̨czności. Datą druku mógłby być rok 1808 lub 1809, miejscem niewątpliwie Warszawa. Oto jego treść:

Stwórca Najwyższy, który światem włada,

Dary dzielności w przeznaczeniu składa;

Cesarzu Francji oraz królu włoski,

Tyś Jego dziełem, namieśnik jest Boski,

5 Moc ci nadana przy twym sławnym tronie,

Byś zrządził krajmi sam, Napoleonie.

Takiego właśnie gdy nam i potrzeba,

Więc cię zesłały najłaskawsze nieba,

Byś chciwe strącał, znikłe wskrzeszał rody,

10 Dumnym zlał kary, pokornym swobody,

A żeś jest mężny, dla ludzkości tkliwy,

Pewnie ród ludzki zostanie szczęśliwy,

Twoja przy Bogu jest szczera opieka,

Do której każdy chętnie się ucieka,

15 Przeto jak Polak wiekiem osiwiały

Udać się do cię byłem łatwo śmiały.

Sto dziewiętnaście lat życia liczący,

Zawsze ojczyzny powrotu życzący,

Dziękując Bogu, że me życie zwlekał,

20 Umrę spokojny, gdym się jej doczekał,

O czym gdy już wiem, widzę, czuję, słyszę,

Teraz ci stan mój pożycia opiszę:

${ }^{32}$ Zob. S. Szenic, Cmentarz Powazkowski 1790-1850. Zmarli i ich rodziny, Warszawa 1979, s. 125-126; autor powtarza tu w zarysach poprzednie wzmianki o Narockim (zob. tenże, Larum na traktach Warszawy, op. cit.) bez podtrzymania przypuszczeń dotyczących „blagierskiej” supliki i uściślając dane biograficzne. 
Młode me siły w wojsku poświęciłem

I tam też szczupły majątek straciłem,

25 Służąc za króla naszego polskiego

Świętej pamięci Augusta Trzeciego.

Później po barskiej nieszczęśliwej doli

Byłem w moskiewskiej przez lat sześć niewoli,

Z której na wolność chociaż wypuszczony,

30 Lecz z sił opadły, w niemoc obarczony,

Nie mogąc więcej mej ojczyźnie służyć,

Spoczynku w roli starałem się użyć.

Krytyczne czasy wciąż dla nas nastały,

Gdy przemoc obca i nierząd władały,

35 Życie pod mieczem, majątki pożarom,

Podległe były nieludzkim poczwarom,

Jednak nadzieją słodką się cieszyłem,

Którą dziś ledwie szczęśliwie przeżyłem.

W żądanej uldze nikt nam nie zaradził,

40 Ciebie Bóg przecież za zbawcę sprowadził,

Spieszno więc biedny gdym zwiedził twe progi,

Żyąc w ojczyźnie, jednakże ubogi,

Gdym z prośbą wyrzekł „Rogo Caesar panem”,

W lot się twa dobroć wzniosła nad mym stanem;

$45 \mathrm{~W}$ tym jest widoczna sprawy Bożej władza,

Gdy nam ojczyznę i nędze osładza

Ojcowska żądna twa ludzkości dusza,

Która nad losem dzieci swych się wzrusza.

Okryty łaską w sił zdrowia się wzmagam,

50 Za ciebie Boga, mój cesarzu, błagam,

Składając temu me pokorne dzięki,

Że nam Polakom zesłał z swojej ręki.

Rządzić ci państwy należy jedynie,

Zwłaszcza wszechwładny w każdej już krainie;

55 Każdy ci naród hołdować gotowy

Pod twą łaskawość zniżą swoje głowy,

Ile gdy Bóg cię na ten świat objawił,

Więc równie zrządził, byś się na nim wsławił.

Panuj swobodnie na szczęśliwym tronie,

60 Wielki i zbawco nasz Napoleonie.

Te jednostajnym są już wszystkich głosy,

Które ci szlemy pod same niebiosy.

Naród nasz polski gdy za twoją sprawą

Zwrócony będzie, z dawną swoją sławą 
65 Zagoi smutne zadane mu blizny,

Stanie się wdzięczny, wielki, mężny, żyzny,

Te me żądanie $z$ rodakami łączę,

Natenczas życie już szczęśliwy skończę.

Wiersz Narockiego, jeśli nadal, jak w przypadku petycji, założymy jego własne autorstwo, potwierdza wyglądający na przesadny opis w „Gazecie Warszawskiej”, że ów Zagłoba nawet „przytacza autorów klasycznych rozsądnie i do rzeczy”33. Oto bowiem dziękujące za przywrócenie ojczyzny wyrazy pod adresem Napoleona (w. 9-10) to wyraźne echo sławnych przykazań dla Rzymian, wyrażanych przez Wergiliusza w Eneidzie (VI, 852-854):

Rzymianinie, $\mathrm{z}$ innej twa szkoły płynie sława!

Ty berłem świetnowładnym pisz pokoju prawa,

Ty losem wojen szafuj, a glowy pokorne

Łaskawie tuląc, ścieraj umysły oporne ${ }^{34}$.

Podtrzymać też należy uznanie dla świadomości retorycznej (mniej zaś poetyckiej) autora. Oto bowiem wspominając audiencję Narocki przytacza w oryginale (w. 43) łacińskie słowa oracji, dając znać nie tylko, że był to szczególny i wnikający w pamięć moment spotkania z Człowiekiem Wieku, ale że miejsce to w petycji autor dopracował starannie jako moment kulminacyjny krótkiego tekstu. Wzmocnieniu tego efektu na pewno oprócz figury myśli (treści wezwania Ojca Ojczyzny) służyła nieprzypadkowa figura słowna (rytm trocheiczny i aliteracja): „a restauratore et patre patriae peto panem”.

Według tych sędziwców — pisze o starcach Warszawy początku XIX wieku Kazimierz Władysław Wójcicki — nauka i książka przystawała jedynie księdzu jezuicie; dla szlachcica dosyć tego, czego się w szkołach wyuczył, a po dworach panów doświadczeniem i otarciem douczył. Literaturę ich całą składał kalendarz, Nowe Ateny, kilka kronik polskich, herbarz Paprockiego lub Niesieckiego i Volumina legum ${ }^{35}$.

Narocki, wyjątkowy jako bios, nie wyróżnia się szczególnie jako logos, ale nie mieści się też w tak zarysowanym stereotypie - być może po prostu płytkim i niesprawiedliwym.

Napoleon spotykał jeszcze zapewne nieraz okazy długowieczności — jak w roku 1811:

${ }^{33}$ Dodatek do „Gazety Korespondenta” nr 17 z 28 II 1807 (sobota), s. 268.

${ }^{34}$ Thum. Adama Naruszewicza [w:] tenże, Dzieła, t. 4: Ttumaczenia, s. 233 (Niektóre fragmenta $z$ not Tacyta ttumaczonego wyjęte - Do Rzymian z Wirgillijusza]).

${ }^{35}$ K. W. Wójcicki, op. cit., s. 8. 
W jednym z małych holenderskich miasteczek miejscowi notable poprosili Cesarza, aby zezwolił przedstawić sobie starca, który dożył stu jeden lat. Cesarz polecił go przywołać. Był to mężczyzna jeszcze czerstwy, dawny żołnierz gwardii stadhoudera: stanąwszy przed Cesarzem złożył mu prośbę o zwolnienie od służby wojskowej jednego z wnuków, który był podpora jego starości. Najjaśniejszy Pan odpowiedział mu przez tłumacza, że nie pozbawi go wnuka. Marszałek Duroc zaś na polecenie Cesarza zostawił temu starcowi namacalny dowód monarszej szczodrości. (... $)^{36}$.

Nigdzie jednak pewnie nie spotkał tak zasługującego na miano swojego „starego wiarusa” żołnierza jak ów „dziarski konfederat barski” spod Wilna, któremu po setce z hakiem chciało się jeszcze utrwalić nieporadnym, serdecznym wierszem radość z powrotu za sprawą Napoleona swojej ojczyzny, tej Polski tak okrojonej i tak w ówczesną „tęczę Franków” wpatrzonej.

Polacy, ci Francuzi Północy, dzielni i lekkomyślni jak my, mówili naszym językiem; kochali nas jak braci, ginęli dla nas z wiernością, w której pobrzmiewała nienawiść do Rosji. Francja zgubiła ich ongi; powinna była przywrócić im życie: czy nie należało się temu narodowi, wybawcy chrześcijaństwa? ${ }^{37}$

36 L. W. Constant, Pamiętniki kamerdynera cesarza Napoleona I, przeł. T. Evert, przedm. i przyp. J. Skowronek, Warszawa 1972, s. 188 (rozdz. XX).

${ }^{37}$ F.-R. de Chateaubriand, Pamiętniki zza grobu, wyb., przekł. i koment. J. Guze, Warszawa 1991, s. 329 (cz. III, ks. XX, rozdz. 12 Cesarz u'yprau'ia się do Rosji. — Sprzeciuy. - Bląd Napoleona). 